\title{
TARTU RADIOCARBON DATES VII
}

\section{ARVI LIIVA, ILPO EKMAN and TOIVO RINNE}

Institute of Zoology and Botany, Academy of Sciences, Estonian SSR Institute of Geology, Karelian Branch of Academy of Sciences, USSR

The present list contains dates of geologic samples from the southern part of the Karelian ASSR and partly from the northwest Leningrad Region, USSR, made in 1969-1975.

Measurement of the activity of ${ }^{14} \mathrm{C}$ was performed by liquid scintillation with the use of benzene. All dated samples were measured in parallel on two single-channel units. Radiocarbon dates have been calculated using $5568 \pm 30$ as the half life of ${ }^{14} \mathrm{C}$, with 1950 as the reference year. ${ }^{13} \mathrm{C} /{ }^{12} \mathrm{C}$ measurements have not been made and results not corrected for ${ }^{13} \mathrm{C}$ fractionation.

\section{TA-487. Golikovka}

\section{Karelian ASSR} Petrozavolsk, 500m S of RR Sta Golikovka. Alt of peat layer cats Sample coll from 170 to $190 \mathrm{~cm}$ depth.

Pollen analysis by A Kolkanen of a peat sample indicates presence of pine forests with admixture of birch and permanent presence of broadleaved tree species (oak, elm, hornbeam) and hazel. Comment: date agrees with time of climatic optimum of Second Late Pleistocene of inter-Glacial period (mid-Valdai). Sample coll and subm 1972 by A Liiva and I Ekman.

\section{Uuksunlahti series}

Samples coll from excavation on terrace of Lake Ancylus, surface alt 18 to $21 \mathrm{~m}$, on SE shore of Uuksunlahti Bay of Lake Ladoga $2 \mathrm{~km} \mathrm{SE}$ of Ala-Uuksu, Pitkäranta Dist. Pollen analysis by A Kolkanen, diatom analysis by M Traving. Samples coll and subm 1970-197॥ by I Ekman and A Liiva.

\section{TA-411. Uuksunlahti I a}

$8760 \pm 100$

Wood from large sunken tree trunk, from sand layer at 150 to $160 \mathrm{~cm}$ depth formed in shallow water, according to diatom analysis. Pollen analysis attributes sample to Boreal period (prevalence of pine and birch).

\section{TA-379. Uuksunlahti I b}

$8170 \pm 80$

Well-preserved lake grasses over reeds and sedges from sand layer of Lake Ancylus at 125 to $130 \mathrm{~cm}$ depth. According to composition of diatoms, grasses developed in period of maximum Ancylus transgression in Ladoga basin.

TA-417. Uuksunlahti I e $7500 \pm 90$

Strongly decomposed peat passing over to gyttja. Sample coll from lower layer of peatbog at 65 to $70 \mathrm{~cm}$ depth. 
TA-256. Uuksunlahti I d

Wood (birch), diam ca $6 \mathrm{~cm}$. Sample coll from leeward slope of sand dune at 70 to $90 \mathrm{~cm}$ depth of aeolian sands, which disclosed fine-grained sands of Lake Ancylus.

General Comment: 1st stage of largest aeolian formations in the Holocene started on the boundary of Atlantic and Sub-Boreal periods (ca 4900 to $4700 \mathrm{BP}$ ), brought about by the (levelopment of Sub-Boreal transgression of Lake Ladoga on its $\mathrm{N}$ shore.

TA-362. Uuksunlahti II

$2175 \pm 120$

Wood from excavation $320 \mathrm{~km} \mathrm{~S}$ of Uuksunlahti I profile (nearer to the shore of Ladoga). Sample coll 1970 at 50 to $110 \mathrm{~cm}$ depth from layered sands covered by embankment of sand and pebble (alt 15 to $16 \mathrm{~m}$ ) of 2nd early-Sub-Atlantic Ladoga transgression. Subm by I Ekman.

\section{Uuksunlahti Series III}

Wood and peat from shallow prospecting hole (alt 7 to $9 \mathrm{~m}$ ) 300 to $310 \mathrm{~m} \mathrm{~S}$ of Uuksunlahti II profile, ca $200 \mathrm{~m}$ from present-day scarp of Lake Ladoga. In the outcropping beneath lake sands were 2 layers of peat and wood. According to pollen analysis, subm by M Guman, peat and underlying sands accumulated in lst half of Sub-Atlantic transgression period. General Comment: dates confirm existence of a 2nd, later Sub-Atlantic transgression period whose maximum occurred ca 2000 BP (cf TA-362). It was preceded by chief, Sub-Boreal, stage of transgression of Lake Ladoga with maximum rise of water level in $\mathrm{N}$ part of basin in 3000 to 3100 BP (cf TA-354, -355). Samples coll and subm 1970 by I Ekman.

\section{TA-363. Uuksunlahti III a}

$2280 \pm 70$

Peat from depth 36 to $42 \mathrm{~cm}$.

\section{TA-364. Uuksunlahti III b}

$2240 \pm 80$

Wood from trunk lying at depth 32 to $40 \mathrm{~cm}$.

\section{TA-285. Ristioja}

$8690 \pm 100$

Wood peat from a boring lying at $4 \mathrm{~km}$ SE of town Pitkäranta. In the profile, layered sands are underlain by $6 \mathrm{~cm}$ peat overlying sand.

Pollen analysis indicates that accumulation of lower layer of sand and peat proceeded in 1st half of Boreal period, whereas accumulation of upper sand bed took place in 2nd half of Boreal period and ended at beginning of Atlantic period. Deposits of transgressive and regressive stages of development of lake (Lak and Ekman, 1975) were found in profile of lake sands at base of composition of cliatoms.

General Comment: samples confirm existence of bay of Lake Ancylus in Ladoga basin of ancient Baltic area (2nd half of Boreal period). Regression of water ended on boundary of Boreal and Atlantic periods. Depth of maximum water level of Ancylus transgression in dist of town Pitkä- 
ranta did not exceed 21 to $23 \mathrm{~m}$. Sample coll 1969 at 155 to $161 \mathrm{~cm}$ depth and subm by I Ekman.

\section{TA-587. Heposelkä I}

Herbaceous peat from boring $5 \mathrm{~km}$ SSE of town Pitkäranta; surface alt ca $18 \mathrm{~m}$. Sample coll from lower part of peat bed at 265 to $270 \mathrm{~cm}$ depth from surface. According to pollen analysis by A Kolkanen, sample is attributed to layer formed on boundary of Boreal and Atlantic periods. Comment: dates end of regression of Iake Ancylus and transition of lake stage into swamp stage. Sample coll and subm 1973 by H Goryunov and I Ekman.

\section{Heposelkä Series II}

Well-preserved organogenous materials from profile $5 \mathrm{~km}$ SSE of town Pitkäranta, buried under ancient beach barrier. Thickness of organogenous deposits ranges from 85 to $90 \mathrm{~cm}$, alt $18.5 \mathrm{~m}$. Pollen analysis by A Sarv. Samples coll and subm 1969 to 1970 by I Ekman.

\section{TA-353. Heposelkä II a}

$5970 \pm 80$

Wood and reed peat from 330 to $340 \mathrm{~cm}$ depth. Comment: dates peat accumulation on outskirts of swamp, beginning of whose formation followed regression of Lake Ancylus ( $c f$ TA-587) on boundary of Boreal and Atlantic periods.

\section{TA-286. Heposelkä II b}

$4150 \pm 90$

Wood peat from 280 to $290 \mathrm{~cm}$ depth.

\section{TA-354. Heposelkä II c}

$3070 \pm 70$

Peat from uppermost layer of organogenous bed; depth varies from 255 to $260 \mathrm{~cm}$. Comment: 2nd half of Sub-Boreal period. Dates maximum Ladoga transgression on $\mathrm{N}$ shore ca 3000 to 3050 yr вP (Liiva et al, 1971; Ekman et al, 1975).

\section{TA-355. Heposelkä II d}

Wood from tree trunk buried in upper peat bed at 255 to $265 \mathrm{~cm}$ depth. Comment: date confirms maximum Ladoga transgression determined earlier (cf TA-354).

\section{Lysinvaara Series I}

TA-590. Lysinvaara I

$7950 \pm 110$

Arboreal-herbaceous peat from paludified lagoon of Lake Ancylus $1.6 \mathrm{~km} \mathrm{NW}$ of mouth of Uuksunjoki R (on outskirts of Ala-Uuksu, Pitkäranta Dist). Alt of peat bed ca 21 to $22 \mathrm{~m}$. Sample from lowermost peat horizon at 172 to $177 \mathrm{~cm}$ depth. Palynologic analysis by A Kolkanen attributes sample to Boreal period (short-lived local prevalence of birch in stands). Comment: dates beginning of drying up of lagoon as result of regression of Lake Ancylus. Sample coll 1973 and subm by I Ekman. 


\section{Lysinvaara Series II}

Peat from excavation $100 \mathrm{~m} \mathrm{E}$ of Lysinvaara I profile on top of beach barrier formed in period of maximum Sub-Boreal Ladoga transgression. Alt of peat ca $19 \mathrm{~m}$. According to pollen analysis by A Kolkanen, buried peat was formed in Sub-Boreal period. Sample coll and subm 1973 by I Ekman.

TA-588. Lysinvaara II a

$4250 \pm 100$

Peat coll from 135 to $140 \mathrm{~cm}$ depth. Comment: dates approach to high level of lake transgression, which was close to its maximum.

TA-694. Lysinvaara II b

$3590 \pm 80$

Peat coll from 120 to $125 \mathrm{~cm}$ depth.

TA-589. Lysinvaara II c

$3560 \pm 60$

Peat coll from 100 to $105 \mathrm{~cm}$ depth, underlain by sand at 105 to $120 \mathrm{~cm}$ depth. Comment: dates short break in peat accumulation (cf TA-694).

TA-695. Lysinvaara II d

$\mathbf{3 3 5 0} \pm \mathbf{8 0}$

Peat from 95 to $100 \mathrm{~cm}$ depth. Comment: date confirms approx maximum of Ladoga transgression.

\section{Uuksunjoki Series I}

Buried organic materials from profile of Holocene deposits on left bank of Uuksunjoki R $1 \mathrm{~km} \mathrm{~N}$ of estuary and 150 to $200 \mathrm{~m}$ below RR bridge (Pitkäranta Dist); alt of embankment is $13.5 \mathrm{~m}$. Sample coll 1971 and subm by I Ekman.

TA-418. Uuksunjoki I a

$5230 \pm 70$

Wood from large tree trunk coll from lower layers of delta deposits at 182 to $195 \mathrm{~cm}$ depth.

General Comment: date confirms lower limit of development of Ladoga transgression on $\mathrm{N}$ shore of lake (cf TA-256). Date agrees with data obtained by M Saarnisto (1970) concerning beginning of transgresion.

\section{TA-419. Uuksunjoki I b}

$7300 \pm 100$

Wood from a trunk fragment buried in $\mathrm{N}$ part of delta deposits at 145 to $155 \mathrm{~cm}$ depth. Comment: date does not agree with result of a pollenanalysis (Sub-Boreal period). Fragment of tree trunk was obviously redeposited from earlier formations.

TA-422. Uuksunjoki I c

$2615 \pm 70$

Peat with fragments of wood from upper horizon of delta deposits (depth 130 to $135 \mathrm{~cm}$ ). Comment: dates end of chief stage of Ladoga transgression, followed, after a break of 200 to $400 \mathrm{yr}$, by another rise in lake level similar in scope and duration (cf TA-362-364).

TA-452. Uuksunjoki II $5215 \pm 70$

Fragments of wood from outcropping on bank of Uuksunjoki 80 to $85 \mathrm{~m}$ downstream from profile of Uuksunjoki I ( $c f$ TA-422). Samples coll 
at 265 to $270 \mathrm{~cm}$ depth from lower bed of lake deposits. Comment: dates initial stage of development of Ladogatransgression on $\mathrm{N}$ bank (cf TA418). Samples coll and subm 1971 by I Ekman.

\section{Uuksunjoki Series III}

Outcropping on left bank of Uuksunjoki $\mathrm{R} 25 \mathrm{~m}$ downstream from profile of Uuksunjoki I (see above). Deposits are similar to outcropping of Uuksunjoki II. Samples coll and subm 1971 by I Ekman.

\section{TA-451. Uuksunjoki III a}

$$
2810 \pm 80
$$

Peat from organogenous layer at 220 to $225 \mathrm{~cm}$ depth in lower reaches of deltaic deposits. Date does not agree with pollen-analytic and radiocarbon clata of adjacent profiles ( $c$ T TA-418, -452). For unknown reasons, age of sample is rejuvenated.

\section{TA-450. Uuksunjoki III b}

Wood from tree stub, buried in upper horizon of deltaic deposits at 170 to $185 \mathrm{~cm}$ depth. Rejuvenation of sample age may be due to contamination by rootlets of present-day trees.

\section{Verkhnyi Konets series}

Outcropping on right bank of Megrega R $1.7 \mathrm{~km}$ SW of estuary of Sambatuksa R, at former Verkhnyi Konets (Upper End) Olonets Dist. Samples coll 1973 and subm by I Ekman.

\section{TA-602. Verkhnyi Konets}

$$
4680 \pm 100
$$

Peat from 325 to $330 \mathrm{~cm}$ depth from lower horizon of peat deposits. Comment: dates overgrowth of small lake in middle reaches of Negrea $\mathrm{R}$ in Sub-Boreal period, according to A Kolkanen.

\section{TA-603. Verkhnyi Konets II}

$$
2940 \pm 120
$$

Peat from 195 to $200 \mathrm{~cm}$ depth from uppermost horizon of peat deposits. Comment: dates end of accumulation of peat as result of maximum level of Ladoga transgression on $\mathrm{E}$ bank of Ladoga.

\section{Megrega series}

Buried organic formations from profile on right bank of Megrega $R$, $1.1 \mathrm{~km}$ NE of bridge in centre of profile of same name, Olonets I)ist. Outcropping is within limits of underdeveloped delta (surface alt ca $13 \mathrm{~m}$ ) at time of regresion of Lake Ladoga. Samples coll and subm 1973 by I Ekman. Pollen analysis by A Kolkanen; diatom analysis by H Lak.

\section{TA-604. Megrega I}

$5510 \pm 120$

Wood from large alder stump, buried at 320 to $340 \mathrm{~cm}$ deptll in zone of contact with underlying aleurite. Comment: date confirms short flooding of depression in Megrega $\mathrm{R}$ valley in 2nd half of Atlantic period. 
TA-605. Megrega II

$4950 \pm 120$

Peat from 315 to $320 \mathrm{~m}$ depth, 2nd half of Atlantic period. Comment: dates beginning of peat accumulation in depression in middle reaches of Megrega R.

\section{TA-606. Megrega III}

590 вC depth.

Peat from beneath sediments of Ladoga transgression at 250 to $255 \mathrm{~cm}$

\section{TA-607. Megrega IV}

Wood from a large fragment of tree trunk from $1.3 \mathrm{~m}$ depth. Comment: date apparently confirms existence of late Sub-Boreal stage of transgression in history of development of Lake Ladoga (Ekman et al, 1975).

TA-608. Megrega $V$

$1600 \pm 150$

Finely scattered organic substance from 105 to $110 \mathrm{~cm}$ depth. Comment: obvious rejuvenation of sample from unknown causes.

\section{Rauda series}

Outcropping on steep right bank of Rauda streamlet close to confluence with Obzhanka R, Olonets Dist in its lower reaches. Alt of brow of scarp is 8 to $9 \mathrm{~m}$. Pollen analysis by A Kolkanen; diatom analysis by H Lak. Samples coll and subm 1973 by H Goryunov and I Ekman.

\section{TA-611. Rauda I}

$4920 \pm 100$

Wood from 205 to $220 \mathrm{~cm}$ depth buried in contact layer between aleurite (Atlantic period) and peaty gyttja (transitional interval of SubBoreal period). Comment: evidently dates decline of water level and beginning of overgrowth of isolated lake in lower reaches of Obzhanka $\mathbf{R}$.

\section{TA-609. Rauda II}

$4600 \pm 120$

Peat from contact zone with underlying gyttja from 180 to $185 \mathrm{~cm}$ depth. Comment: dates beginning of peat accumulation after disappearance of lake in Sub-Boreal period.

\section{TA-610. Rauda III}

$$
1310 \pm 80
$$

Peat from 160 to $165 \mathrm{~cm}$ depth. Undoubtedly, rejuvenation of sample.

\section{TA-416. Koirinoja}

$470 \pm 80$

Wood coal from quarry in region of lower reaches of Koirinoja $\mathrm{R}$ right bank, near bridge, Pitkäranta Dist. Sample coll 1971 from 100 to $110 \mathrm{~cm}$ depth, subm by A Liiva and I Ekman.

\section{TA-517. Burnaya}

$$
\text { Leningrad Region }
$$

Peaty gyttja from 122 to $126 \mathrm{~cm}$ depth of lowest horizon of bog and lake deposits on right bank of Burnaya R, formerly Taipalenjoki, $1.5 \mathrm{~km}$ 
from estuary, Priozyorski Dist. Alt of river bank ca $14 \mathrm{~m}$. Gyttja apparently accumulated in isolated lake in Pre-Boreal period, according to pollenanalysis by A Kolkanen. Sample coll and subm 1972 by H Lak and I Ekman.

\section{Vyun Series I}

Buried organic formations from outcropping of former lacustrine terrace, surface alt $14 \mathrm{~m}$, on right bank of Vyun $R$, formerly Viisijoki $R, 150 \mathrm{~m}$ below hwy bridge between Zaporozhckoye and Pyatireshye, Priozyorsky Dist. According to literature (Znamenskaya and Ananova, 1967; Znamenskaya et al, 1970) lower layer of sediments was formed in Atlantic period in Sub-Boreal while upper layer was formed in Sub-Atlantic period. Sample coll and subm 1972 by H Lak and I Ekman.

\section{TA-488. Vyun I a}

Wood from buried aleurite horizon coll at 580 to $590 \mathrm{~cm}$ depth from alder trunk. Deposits accumulated in shallow lake near mouth of ancient streamlet.

\section{TA-512. Vyun I b}

$3510 \pm 100$

Wood peat from 420 to $425 \mathrm{~cm}$ depth. Comment: dates beginning of peat accumulation after disappearance of lake in lower reaches of Vyun $R$.

\section{TA-489. Vyun I c}

Peaty gyttja and peat from 313 to $318 \mathrm{~cm}$ depth of contact zone. Acmulation of cleposits of Lake Ladoga occurred in bay, a kind of lagoon, isolated from open Ladoga. Comment: date confirms maximum of Ladoga transgression in SW part of lake.

\section{Vyun Series II}

Buried lacustrine and boggy deposits from profile on left bank of Vyun R 100m upstream from profile of Vyun I.

\section{TA-513. Vyun II a}

$$
6570 \pm 70
$$

Fragments of wood from depth of ca $500 \mathrm{~cm}$. Dates accumulation of lower layers of profile in Atlantic period of Holocene.

\section{TA-514. Vyun II c}

Gyttja from depth of 200 to $210 \mathrm{~cm}$ depth. Date confirms time when Ladoga transgression reached maximum shore line in $\mathrm{SW}$ part of Ladoga (cf TA-489).

\section{Syaskie Ryadki series}

Buried organic formations from outcropping on right bank of Syas $R$, on E outskirts of Syakie Ryadki, Volkhov Dist. Alt of bank ca $+13 \mathrm{~m}$. Samples coll and subm 1972 by H Lak and I Ekman. 
TA-515. Syaskie Ryadki I

Peat coll from peat layer at 227 to $232 \mathrm{~cm}$ depth. Comment: dates end cessation of sedimentation in lower reaches of Sääs $R$ at end of Atlantic period, according to pollen analysis by A Kolkanen.

TA-516. Syaskie Ryadki II

$4400 \pm 70$

Wood from 150 to $160 \mathrm{~cm}$ depth from upper part of gyttja bed. Date conforms to early Sub-Boreal transgression stage in S part of Ladoga, with smooth and slow rise in level of earth, which preceded maximum rise (Ekman et al, 1975).

\section{REFERENCES}

Ekman, I M, 1972, On the characterization of organogenous interglacial deposits in the vicinity of Petrozavodsk, in: Chetvertichnaya geologiya $i$ geomorfologiya vostochnoi chasti Baltiskogo shchita (Quaternary geology and geomorphology of the eastern part of the Baltic Shield): Trudy inst geol (Works of Geol Inst), Karelian Branch of USSR Acad Sci, pt 13, Leningrad, p 97-101.

Ekman, I M, Lak, H Ts, and Liiva, A A, 1975, On the history of transgression of Lake Ladoga, in: Istoriya ozyor $\mathrm{v}$ kholotsene (History of lakes in the Holocene), Leningrad, p $38-45$

Lak, H Ts, and Ekman, I M, 1975, On transgressions of Lake Ladoga in the Holocene, in: Doklady AN SSSR, v 222, no. 1, p 175-178.

Liiva, A A, Sarv, A A, and Ekman, I M, 1971, On the history of the post-Glacial (Holocenic) development of Ladoga on the basis of new investigations on the NE shore of Lake Ladoga, in: Priroda, beregovye obrazovaniya i istoriya razvitiya vnutrennykh vodoyomov i morei Vostochnoi Pribaltiki i Karelii (Nature, shore formations in the history of the development of inland water bodies and seas of the eastern Baltic area and of Karelia): Petrozavodsk, p 23-26.

Saarnisto, I W, 1970, The Late Weichselian and Flandrian history of the Saimaa Lake complex: Soc Sci Fennica, Comment Phys Math, v 37, p 1-107.

Znamenskaya, $O$ M and Ananova, E N, 1967, New data on the history of the southern shore of Lake Ladoga, in: Istoriya ozyor Severo-Zapada (History of the lakes of the North-West): Leningrad, p 132-140.

Znamenskaya, O M, Sokolova, V B, and Khomutova, V I, 1970, Comparative analysis of paleographic conditions of development of the southern and western shores of Lake Ladoga, in: Istoriya ozyor (History of lakes): Vilnius, v 2, p 319-331. 